\title{
Composition variation of essential oil of Cymbopogon spp. growing in Garhwal region of Uttarakhand, India
}

\author{
Anju Bhatnagar \\ Departmant of Chemistry, D.B.S. (P.G.) College, Dehradun-248001 (Uttarakhand), INDIA \\ E-mail: anju_bhatnagar_2007@yahoo.com \\ Received: August 8, 2017; Revised received: October 27, 2017; Accepted: February 10, 2018
}

\begin{abstract}
The present study was aimed to find out the chemical constituents of essential oils of cymbopogon species,viz. Cymbopogon martinii var motia, Cymbopogon flexuosus Nees., Cymbopogon winterianus Jowitt., growing in Garhwal region of Uttarakhand, India. The essential oils were obtained by hydro-distillationand subjected to detailed Gas Chromatography-Mass Spectroscopy (GC-MS) analysis in order to determine the variation in their volatile constituents. Twenty seven compounds are $\alpha$-pinene, $\beta$-myrcene, Limonene, Cis-b-Ocimene, $p$ Cymene ,Terpinolene,6-Methyl hept-5-en-2-one, Citronellal, Linalool, Linalyl acetate, $\beta$-Elemene, $\beta$-Caryophyllene, Citronellyl acetate, Neral, a- Terpineol, Borneol,Gerainal, y-Cadinene,Geranyl acetate, Citronellol,Nerol,Geraniol, Caryophyllene oxide,Germacrene-D-4-ol,Elemol, Epi-a-cadinol, $\delta$-Cadinol representing 92.24 to $95.86 \%$ of the oil compositions as identified. While comparing the common constituents of three different species of cymbopogon taxa , the remarkable variation in compositions of essential oil was observed and it was in concentration of nearl $(0.40 ; 34.9 ; 1.6)$, gerainal (nil;47.5;0.96) geraniol $(82.5 ; 4.5 ; 20.15)$, citronellol $(\mathrm{T} ; 0.2 ; 12.39)$, citronellal $(0.1 ; 0.5 ; 36.19)$, and linalool $(0.8 ; 1.6 ; 0.96)$ for C.martini, C.flexuosus, C. winterianus respectively.
\end{abstract}

Keywords: Cymbopogon flexuosus, Cymbopogon martini, Cymbopogon winterianus, Citrals Essential oils, Monoterpenoids

\section{INTRODUCTION}

Cymbopogon is one of the most important essential oil yielding genera of the family Poaceae, comprising about 140 species worldwide, out of which 45 species have been reported to occur in India. The members of the genus Cymbopogon occur abundantly in tropics and subtropics regions of Asia, Africa and America with a regular distribution ranging from mountains and grassland to arid zones (Bor, 1960 ; Soenarko, 1997). Cymbopogon species display wide variation in morphological attributes and essential oil composition at inter and intraspecific level and over the years. The most common economic species viz., Cymbopogon winterianus, Cymbopogon flexuosus, Cymbopogon martinii var. motia and sofia, Cymbopogon nardus var. nardus, Cymbopogon citrates, Cymbopogon pendulus, Cymbopogon warancusa, Cymbopogon khasianus produces different types of essential oil, such as palmarosa oil, lemongrass oil, citronella oil, ginger grass or rusa oil of commercial interest. (Gupta and Jain, 1978).

The essential oils are concentrated, hydrophobic liquid containing volatile aroma compounds from plants, which are called aromatic herbs or aromatic plants. They are also known as volatile or ethereal oils, or simply as the oil of the plants from which they are de- rived, such as camphor oil, peppermint oil, lemon grass oil, etc. Citral is the major constituent which gives a characteristic lemon like aroma to lemongrass oil. The essential oil of lemongrass, palmarosa and citronella has immense commercial values in flavours, fragrances, cosmetics, perfumery, soaps, detergents, toiletry, tobacco products and pharmaceutical (Ganjewala et al., 2009).

Three Cymbopogon kinds of grass, namely, Java citronella (Cymbopogon winterianus), lemongrass (Cymbopogon flexuosus and Cymbopogon pendulus) and palmarosa (Cymbopogon martinii var. motia) are the more common species that are widely cultivated for their essential oils of commercial importance (Gupta and Daniel,1982). The essential oils from Cymbopogon species contain a wide variety of terpenoids, some of which like geraniol and its ester, citronellol and citronellal are important perfume materials. Another constituent like citral is used in vitamin A and ionone synthesis. Several Cymbopogon species possessed significant anthelmintic, anti-inflammatory, analgesic, antiageing, pesticidal, antimicrobial, mosquito repellant and larvicidal activities and thus, are used in native medicine for curing a number of diseases (Khanuja et al., 2005). Studies on the oil composition of various Cymbopogon species have been carried 
out time to time, reports geraniol, geranyl acetate, citral, piperitone, limonene, elemecin, monoterpene alcohols and sesqui-terpenes as the major constituents in their essential oils (Rao, 1997; Kulkarni et al., 1992). In Cymbopogon, the essential oil composition showed significant qualitative and quantitative variation across the species/cultivars (Padalia et al., 2011). The commercial aspects of the essential oils of these aromatic grasses and their cultivars prompted us to carry out detailed comparative terpenoid composition of cultivated species of genus Cymbopogon form (Mathela et al., 1986, Lawrence, 1988) of northern plain of India.

\section{MATERIALS AND METHODS}

Plant material: The fresh plant materials of different cultivars of (Cymbopogon martinii var. motia), (Cymbopogon flexuosus), (Cymbopogon winterianus) were collected from cultivated crops at experimental field of CAP Research Centers, Dehradun in the month of July 2016 and duly identified. The experimental site is located at an altitude of $30 \mathrm{~N}$, longitude of $78.03 \mathrm{E}$ and at an altitude of $435 \mathrm{M}$ and it experiences climate with hot summer and chilled winter. After identification, the voucher specimens of all species were kept in the herbarium of D.B.S (P.G) College Dehradun, Uttarakhand (India).

Isolation of essential oils: The fresh plant leaves were collected from experimental sites and dried at ambient temperature for two days in the laboratory. The dried leaves were cut into small pieces. The dried plant leaves used for the extraction of essential oils.

The plant materials were subjected to hydrodistillation using Clevenger-type apparatus for 3 hours. The essential oil evaporated together with vapour was collected as oil drop after condensation into a closed tube attached to Clevenger apparatus. The essential oil was separated form an aqueous phase using a separating funnel. The oil was dried over anhydrous $\mathrm{Na}_{2} \mathrm{SO}_{4}$ and was stored in sealed vials under refrigeration prior to analysis. The oil yields were calculated on the basis of the fresh weight of the material $(\mathrm{v} / \mathrm{w})$.

Gas chromatography-mass spectroscopy analysis: The essential oil was analyzed using Agilent 6890N GC coupled with flame ionization Detector FID). The analysis was carried using HP-5 (30mx0.32mm;0.25 $\mu \mathrm{m}$ film thickness) capillary column. The injector and detector temperature were $210^{\circ} \mathrm{C}$ and $280^{\circ} \mathrm{C}$ respectively Nitrogen was used as carrier gas at a flow rate of $1 \mathrm{ml} / \mathrm{min}$ over temperature programmedwere $60-210^{\circ} \mathrm{C}$ at the rate of $30{ }^{\circ} \mathrm{C} / \mathrm{min}$; finally, held isothermally for $20 \mathrm{~min}$. The identification of compound was carried out by comparison of their relative retention time values with those of authentic standards

The GC-MS analysis of the oils was carried out on Perkin Elmer clarus 500 GC interfaced with a Perki-

Table 1. Comparative chemical composition of the commercially grown cultivars of Cymbopogon Spreng.

\begin{tabular}{|c|c|c|c|c|c|}
\hline Sl.No. & Constituents & RT min & C. martini (\%) & C. flexuosus (\%) & C. winterianus (\%) \\
\hline 1. & $\alpha$-pinene & 3.04 & - & 0.1 & 0.2 \\
\hline 2. & $\beta$-myrcene & 3.46 & 0.2 & - & 0.19 \\
\hline 3. & Limonene & 4.13 & 0.7 & 1.2 & 3.56 \\
\hline 4. & Cis-b-Ocimene & 5.02 & - & $\mathrm{T}$ & $\mathrm{T}$ \\
\hline 5. & p-Cymene & 5.35 & - & $\mathrm{T}$ & - \\
\hline 6. & Terpinolene & 5.51 & 0.6 & 0.5 & - \\
\hline 7. & 6-Methyl hept-5-en-2-one & 7.22 & - & 0.5 & $\mathrm{~T}$ \\
\hline 8. & Citronellal & 11.05 & 0.1 & 0.5 & 36.19 \\
\hline 9. & Linalool & 12.22 & 0.8 & 1.6 & 0.96 \\
\hline 10. & Linalyl acetate & 12.36 & - & - & 0.15 \\
\hline 11. & $\beta$-Elemene & 12.54 & - & $\mathrm{T}$ & 0.39 \\
\hline 12. & $\beta$-Caryophyllene & 13,09 & 1.0 & 0.6 & 0.22 \\
\hline 13. & Citronellyl acetate & 15.30 & -- & $\mathrm{T}$ & 4.12 \\
\hline 14. & Neral & 15.40 & 0.40 & 34.9 & 1.6 \\
\hline 15. & $\alpha$-Terpineol & 15.58 & 0.20 & 0.15 & 0.35 \\
\hline 16. & Borneol & 16.48 & $\mathrm{~T}$ & 1.01 & $\mathrm{~T}$ \\
\hline 17. & Gerainal & 17.22 & - & 47.5 & 0.96 \\
\hline 18. & $\gamma$-Cadinene & 17.55 & 0.10 & $\mathrm{~T}$ & 1.01 \\
\hline 19. & Geranyl acetate & 18.12 & 4.50 & 0.4 & 3.70 \\
\hline 20. & Citronellol & 18.42 & $\mathrm{~T}$ & 0.2 & 12.39 \\
\hline 21. & Nerol & 19.20 & 0.40 & $\mathrm{~T}$ & 0.25 \\
\hline 22. & Geraniol & 21.08 & 82.5 & 4.54 & 20.15 \\
\hline 23. & Caryophyllene oxide & 24.15 & 0.20 & $\mathrm{~T}$ & 2.21 \\
\hline 24 & Germacrene-D-4-ol & 25.40 & - & 0.1 & 2.36 \\
\hline 25 . & Elemol & 27.56 & - & - & 4.90 \\
\hline 26. & Epi- $\alpha$-cadinol & 31.34 & 0.54 & $\mathrm{~T}$ & - \\
\hline \multirow[t]{2}{*}{27.} & $\delta$-Cadinol & 33.65 & 0.2 & $\mathrm{~T}$ & 0.13 \\
\hline & 0 il content $(\%)^{*}$ & & 92.24 & 93.71 & 95.86 \\
\hline
\end{tabular}

Fresh wt basis $\mathrm{t}=$ trace $(<0.10 \%),(-)=$ absent 
nElmer Clarus 500 mass spectrometer fitted with an RTX-5 capillary column $(60 \mathrm{~m} \times 0.32 \mathrm{~mm}$ i.d., film thickness $0.25 \mu \mathrm{m})$. The oven column temperature ranged from $60^{\circ} \mathrm{C}-210^{\circ} \mathrm{C}$, programmed at $3^{\circ} \mathrm{C} / \mathrm{min}$, with initial and final hold time of $2 \mathrm{~min}$, using $\mathrm{He}$ as carrier gas at 10 psi constant pressure, a split ratio of 1:50, an injection size of $0.02 \mu \mathrm{L}$ neat, injector, transfer line and source temperatures were $210^{\circ} \mathrm{C}$; ionization energy $70 \mathrm{eV}$; mass scan range 40-450 amu.

Identification of constituents: Identification of constituents were made on the basis of retention time, Retention Index (RI, determined with reference to homologous series of n-alkanes $\left(\mathrm{C}_{9}-\mathrm{C}_{26}\right.$, Polyscience Corp., Niles IL) under identical experimental condition), coinjection with standards (Aldrich and Fluka), mass spectra library search (NIST/EPA/NIH version 2.1 and Wiley registry of mass spectral data 7 th edition) and by comparing with the mass spectral literature database (Adams, 1995; Davies, 1990). The relative amounts of individual components were calculated based on GC peak areas without using correction factors.

\section{RESULTS AND DISCUSSION}

The essential oil extracted from leaves of three different species of Cymbopogon taxa and subjected to detailed GC-MS analysis in order to determine the variations in their volatile constituents. The results based on the comparison on essential oil constituents of Cymbopogon species, i.e.(Cymbopogo martinii var. motia), (Cymbopogon flexuosus), and (Cymbopogon winterianus), cultivated in Dehradun, a Tarai area Garhwal region of Uttarakhand, India. The essential oil yield was found to vary from $(0.8 \%-1.0 \%)$ in leaves of Cymbopogon martinii var. motia. Similarly, the oil yields varied from $(0.5 \%-1.0 \%)$ of Cymbopogon flexuosus; while in Cymbopogon winterianus, it varied from $(0.8 \%$ to $1.1 \%)$. The GC-MS analysis of the essential oils led to the identification of 27constituents forming $92.24 \%$ to $95.86 \%$ of the total oil compositions (Table 1). Monoterpenoids (89.3\%to $92.36 \%$ ) constituted the major proportion of oil composition of the studied aromatic grasses (Padalia et al., 2011).

The major constituents of C. martinii var. motia were geraniol $(82.5 \%)$, geranyl acetate $(4.5 \%)$ along with limonene $\quad(0.7 \%)$, epi- $\alpha$-cadinol $0.54 \%), \quad \beta$ Caryophyllene $(1.0 \%)$, linalool $(0.8 \%)$ and terpinolene $(0.6 \%)$. The essential oil extracted from leaves was dominated by oxygenated monoterpenoids (90.84\%), the present results are in good agreement with earlier findings (Ganjewala, 2009). The gas chromatographic analysis of essential oil of C.flexuosus has revealed the presence of several monoterpenesi.e. Citrals (a racemic mixture of two isoforms geranial and neral), geraniol, borneol, and 6-methyl hept-5en-2-one, geranyl acetate, pinene, $\beta$-caryophyllene, germacrene-D., and Y-cadinene. The citral content is (geranial: $47.5 \%$, nearl: 34.9), geraniol (4.54\%) and $\beta$-caryophyllene $(0.6 \%)$. Other constituents identified in significant amount were limonene $(1.2 \%)$, and geranyl acetate $(0.4 \%)$. The citral has immense commercial significance due to their characteristic lemon-like aroma to the essential oil.

The phytochemical analysis of the essential oils of C. winterinus showed the presence of citronellal (36.19\%), geraniol $\quad(20.15 \%)$, citronellol $\quad(12.39 \%)$, geranyl acetate $(3.70 \%)$, neral $(1.6 \%)$, geranial $(0.96 \%)$ elemol $(4.90 \%)$ and limonene $(3.56 \%)$. The essential oil of C.winterianus consisted of 24 compounds as revealed by gas chromatographic analyses. Although the characteristics marker constituents in all studied oils were same however, there were considerable variations in the quantitative make up of the constituents. The essential oil of C. winterianus produced in the Garhwal region is comparable to that produced in the other state of India in term of its major components, i.e.,citronellal and geraniol. However, the oil produced in Andhra Pradesh had a higher amount of citronellal $(50.93 \%)$ and relatively lower percentage of citronellol (6.06\%) , geraniol $(16.67 \%)$ and elemol (1.15\%) (Kaul et al.,1997).

The comparative results showed considerable variation in the quantitative compositions of essential oils obtained from three different cymbopogon species in respect citrals, geraniol citronellal, citronellol content (Ganjewala.2009).The study of essential oil composition and phylogentic relationship in three Cymbopogon taxa revealed marked variation in the essential oil content and compositions of these taxa. Essential oil form c. martinii was rich in geraniol with observed value $(82.5 \%)$ whereas essential oil from Cymbopogon flexuous and Cymbopogon winterianus had very little amount of geraniol. The essential oil extracted from Cymbopogon flexuosus mainly consisted of citral that accounted for (84.4\%). While essential oil of Cymbopogon winterianus had geraniol (20.15\%), citronellal(36.29\%), and citronellol (12.39\%), as major components.

\section{Conclusion}

The study of the essential oil compositions of various Cymbopogon species presented here led to the conclusion that the monoterpene compositions of essential oils markedly varied among the species. The essential oil content and composition are greatly influenced by a number of factors such as genotype/chemotype, an ageographical difference of cultivation, and pedogenetic factors.Therefore, there is huge potential for cultivation of cymbopogon species for the production of quality essential oil in the Garhwal valley area of Uttarakhand, India 


\section{ACKNOWLEDGEMENTS}

The work was supported by the UGC, New Delhi, India under Grant No. 8-4(40)/2015(MRP/NRCB).

\section{REFERENCES}

Adams, R.P. (1995). Identification of essential oil constituents by Gas chromatography/Mass spectroscopy. Allured Publ. Corp., Carol Stream, Illinois.

Bor, N.L. (1960). The Grasses of Burma, Ceylon, India and Pakistan, Pergamon Press, London, pp. 767.

Davies,D.W.(1990). Gas chromatographic retention indices of monoterpenes and sesquiterpenes on methyl silicone and Carbowax 20M phases, J. Chromatograph,503:124

Ganjewala, D. (2009). Cymbopogon essential oil : chemical compositions and bioactivities, International journal of essential oil therapeutics, 3: 56-65.

Gupta, B.K. and Jain, N. (1978). Cultivation and utilization of genus Aromatic Cymbopogon in India, Indian Perfume. 22: 55-68.

Gupta, B.K. and Daniel, P. (1982). Aromatic grasses of India and their utilization: A plea for further research, Pafai J. 4:13-27.

Kaul P.N.,Bhattacharya,A.K.,Singh K.,Rajeswara Rao B. R., (1997) Chemical composition of the essential oil of Java Citronella (C.winterianus Jowitt.) grown in An- dhra Pradesh, Pafai J. 19:20-33.

Khanuja, S.P.S, Shasany,A.K., Pawar, A., Lal. R.K., Darokar, M.P., Naqvi, A.A., Raj Kumar, S.,Sundaresan,V., Lal .N and Kumar,S. (2005). Essential oil constituents and RAPD markers to establish species relationship in Cymbopogon Spreng. (Poaceae), Biochem. Syst. Ecol. 33: 171-186.

Kulkarni, R.N., Mallavarapu,R.R. and Ramesh,S. (1992). The oil content and composition of new variants of $\mathrm{C}$. flexuosus. J. Essent. Oil. Res. 4: 511-514.

Lawrence,B.M. (1988). Progress in essential oil: citronella oil, Perfum. Flav. 23: 80-82.

Mathela, C.S., Pant, A.K., Melkani A.B. and Pant,A. (1986). Aromatic grasses of U.P. Himalaya: a new wild species as a source of aroma chemicals, Sci. Cult. 52: 342-344.

Padalia,R.C., Verma.R.S., Chanotiya,C.S . and Yadav, A. (2011).Chemical fingerprint of the fragrant volatiles of nineteen Indian cultivars of Cymbopogon Spreng. Rec. of Nat. Prod.5(4): 290-299.

Rao, B.L., (1997). Scope for development of new cultivars of Cymbopogons as a Source of Terpene Chemicals (In: S. S. Handa and M. K. Kaul (Eds), Supplement to Cultivation and Utilization of Aromatic Plants), National Institute of Science and Communication, New Delhi, India, pp. 71.

Soenarko,S. (1997). The genus Cymbopogon. Reinwardtia .9:225-226 